\title{
Identification and Efforts to Control Infection Odontoglossum ringspot virus (ORSV) on Orchid
}

\author{
Mahfut \\ Faculty of Mathematics and Natural Sciences, University of Lampung, Lampung, 35145, Indonesia \\ *Corresponding author E-mail: mahfut.mipa@ unila.ac.id
}

\begin{abstract}
Odontoglossum ringspot virus (ORSV) is a orchid virus which infection most widely reported and has spread widely in the world, including in Indonesia. Viral infections can degrade the quality of the orchid plant so it is economically detrimental. To study a disease infection, identification is carried out first to determine the most appropriate method of control. These identification techniques include variations in infection symptoms, host range testing, testing of viral titers, observation of particle morphology, genome detection, and analysis of DNA and amino acid sequences. Efforts to control disease can be done through preventive and eradicative actions chemically, biologically, and based on artificial intelligence.
\end{abstract}

Keywords: disease control, disease identification, orsv, plant viruses

\section{Introduction}

Orchid is one type of ornamental plant that has a high aesthetic value and is the most desirable community [4]. Disease infection is still a major obstacle in the cultivation and development of natural orchid potential [16]. Odontoglossum ringspot virus (ORSV) is one of the orchids viruses that is reported to infect the most. This virus was first discovered in the United States [2] and has spread to other countries including Indonesia. ORSV has quite extensive distribution areas in Java, Ujung Pandang, Kalimantan, Bali, and Papua [4]; [8]; [9]; [11]; [12]; [13]; [16]. In general, ORSV infection results in chloroplast damage [10]; [14].

Pest and disease infections are still a major obstacle in the preservation and development of orchid potential. Viral infections cause a decrease in plant quality followed by a decrease in the sale value of plants so that it is very detrimental to the economy.

\section{Identification of Virus Infection}

In the study of a disease infection, identification is carried out first to determine the most appropriate method of control. Viral infections in orchids will inhibit plant growth and endurance, as well as periodically reducing the aesthetic value. These identification techniques include variations in infection symptoms, host range testing, testing of viral titers, observation of particle morphology, genome detection, and analysis of DNA and amino acid sequences.

Based on previous researchsurvey, it is known that several individual orchids exhibit symptoms of viral disease infections, namely mosaic, chlorotic, streak, and necrosis. [17] reported that orchid plants were able to be infected with more than 25 types of viruses. One of the types of viruses that are reported to infect the most and have the widest spread in the world is the Odontoglossum ringspot virus (ORSV). Viral infections cause a decrease in plant vigor and flower quality resulting in economic losses [6]; [12]; [18]. 


\section{Odontoglossum ringspot virus (ORSV)}

ORSV is a relatively new type of virus found in Indonesia, although it has been known since 1951. Until now ORSV is one of the viruses that are reported to infect most orchids [2] with wide spread in the world including in Indonesia [4].

ORSV infections inhibit growth and reduce the quality of flowers. The spread of this virus can be through mechanical inoculation and contamination of equipment used for vegetative propagation and flower harvesting [17]. This virus can last a long time in pots and cannot be transmitted through vectors [2].

In Indonesia, ORSV has a fairly wide distribution area and is reported to have spread to almost all regions such as Ujung Pandang [4], West Java, Bogor [6]; [12], Magelang [16] and Bali [4]; [16]. The presence of this virus was found in each location observed but the proportion of the incidence of the disease was different for each place. A map of the geographical distribution of ORSV in Indonesia is presented in Figure 1.

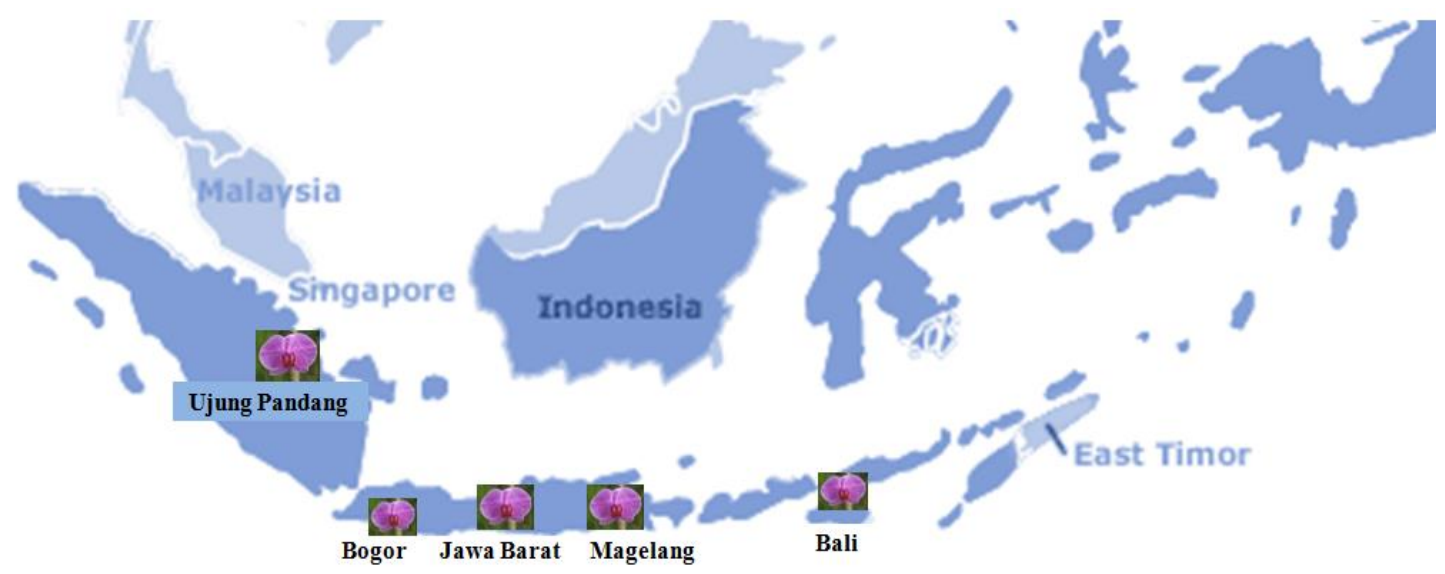

Fig. 1: Map of ORSV geographical distribution in Indonesia. $=$ ORSV distribution area

ORSV or also known as Tobbaco mosaic orchid virus strain (TMV-O) belongs to the genus Tobamovirus [2] and the Virgaviridae family [16]. By using a transmission electron microscope (TEM), ORSV can be seen as longitudinal rigid rods, not enveloped by protein membranes, and consisting of positive single-stranded ribonucleic acid (ssRNA) molecules measuring 6.6 kb [2]. The particle size of this virus is $300 \mathrm{~nm} \times 18 \mathrm{~nm}$, the same as Tobacco mosaic virus [1]; [17].

Several studies report that ORSV has been able to infect 27 orchid genera in the world as shown in Table 1. In Indonesia, ORSV has reportedly infected 9 orchid genera, namely: Aranda, Grammatophyllum, Dendrobium, Phalaenopsis, Bulbophylum, Calanthe, Cattleya, Oncidium, and Coelogyne [18]. ORSV infection can cause different symptoms in orchids. First research reported that ORSV caused ringpot symptoms on the leaves of Odontoglossum grande, where the strain of the virus was first isolated.

Table 1. List of orchid genera reportedly infected with ORSV [18]

\begin{tabular}{|c|c|c|}
\hline No. & Orchid Genera & Reference \\
\hline 1 & Arachnis & Tanaka et al., 1997 \\
\hline 2 & Aranda & Wong et al., 1994 \\
\hline 3 & Bifrenaria & Inouye, 1992 \\
\hline 4 & Brassavola & Hu et al., 1993 \\
\hline 5 & Brassidium & Inouye, 1992 \\
\hline 6 & Brassolaeliocattleya & Wong et al., 1994 \\
\hline 7 & Bulbophyllum & Inouye \& Gara, 1996 \\
\hline 8 & Calanthe & Inouye, 1992; Inouye \& Gara, 1996; Mutsumoto et al., 1996 \\
\hline 9 & Catasetum & Hu et al., 1993 \\
\hline 10 & Cattleya & $\begin{array}{l}\text { Sutabutra \& Smutasin, 1971; Wisler et al.,1982; Inouye, 1992; Hu et al., 1993; Wong et al., 1994; Ryu \& } \\
\text { Park, 1995; Inouye \& Gara, 1996; } \\
\text { Tanaka et al., 1997; Park et al., 1998; La et al., } 1999\end{array}$ \\
\hline 11 & Caularthron & Hu et al., 1993 \\
\hline 12 & Cymbidium & Arunasalam \& Pearson, 1989; Hu et al., 1993; Ryu \& Park, 1995; Kondo et al., 1992; La et al., 1999 \\
\hline 13 & Dendrobium & $\begin{array}{l}\text { Wisler et al., 1982; Hu et al., 1993; Wong et al., } \\
\text { 1994; Park et al., } 1998\end{array}$ \\
\hline 14 & Doritaenopsis & Wong et al., 1994 \\
\hline 15 & Doritis & Wong et al., 1994 \\
\hline 16 & Epidendrum & Inouye, 1992; Hu et al., 1993; Park et al., 1998 \\
\hline 17 & Haemaria & Hu et al., 1993 \\
\hline 18 & Laeliocattleya & Wisler et al., 1982 \\
\hline 19 & Miltonopsis & Park et al., 1998 \\
\hline 20 & Mitonia & Inouye, 1992 \\
\hline 21 & Mokara & Wong et al., 1994 \\
\hline
\end{tabular}




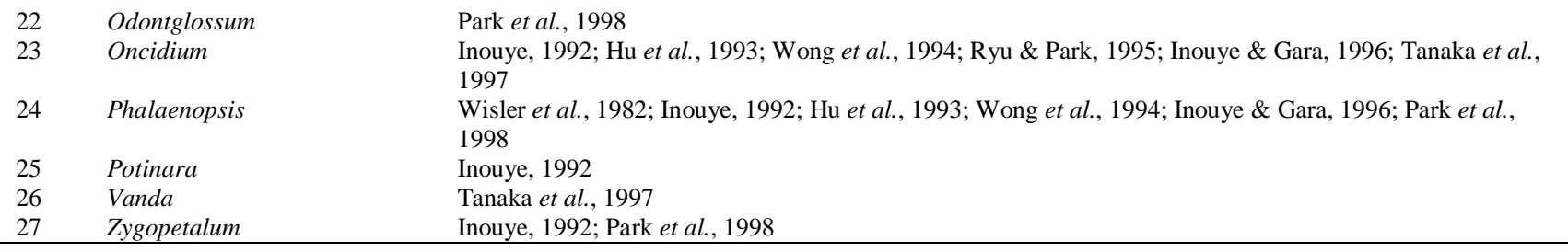

In some orchids such as Cattleya sp. symptoms of infection in the form of lines or chlorotic spots, necrotic, and ring spots, whereas Oncidium sp. in the form of black necrotic spots seen on the underside of the leaf [9]. [6] reported that Dendrobium sp. those who are positively infected can show symptoms not infected (symtompless) or latent symptoms, whereas in Phalaenopsis sp. symptoms of ORSV infection in the form of necrotic, chlorotic, mosaic, and wilting leaves [9]; [12] shown in Figure 2.

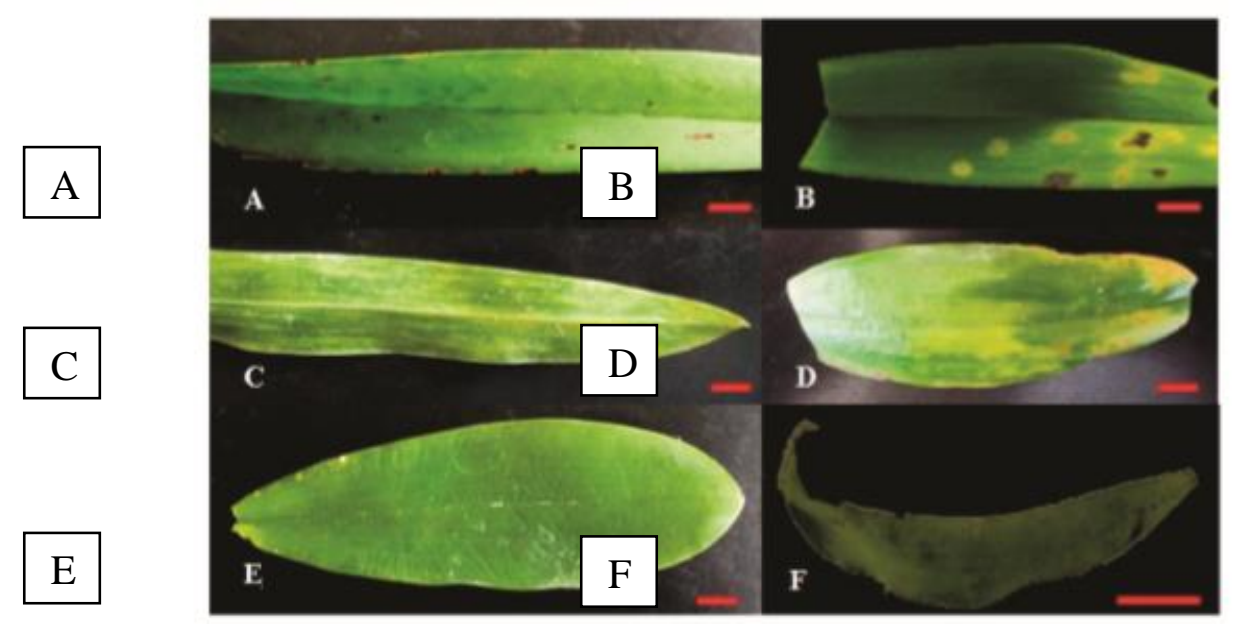

Fig. 2: Symptoms of ORSV infection in natural orchids: (A) chlorotic, (B) mosaic and necrosis, (C) streak, (D) mosaic, (E) wilting leaf, and (F) curling leaf. Bar $=1 \mathrm{~cm}[12]$

[3] explain that viruses can cause different symptoms in different plants, while different viruses can cause similar symptoms in the same host plant. Symptoms caused by ORSV infection in orchids vary greatly depending on virus strains, orchid cultivars, and environmental conditions [13].

[6]; [18] explain ORSV is also able to cause necrotic spots, color breaking, malformations, distortion of shapes, and abnormalities of sepals and petals in orchids. This is what causes huge economic losses because the selling price of orchids is low as a result of the declining quality of orchid flowers [16]. Some symptoms of ORSV infection in orchids are presented in Figure 3.

ORSV can also infect orchids together with CymMV called multiple infections [4]. [6] explains that multiple infections of CymMV and ORSV are more severe than single infections of each virus. Likewise the incubation period is seen earlier and the total incidence in plants is greater than a single infection of each virus.

Research related to the analysis of nucleotide sequence mutations and amino acid changes in ORSV is generally carried out in part of the genome virus. ORSV gene detection is carried out on conserved parts of the virus sequence so that it is stable and very few mutations occur, namely Coat Protein $(\mathrm{CP})$.

The effect of mutations that occur is capable of causing changes in the amino acid encoding codlet triplets in the composition of the viral genome. Changes in amino acids will change the function of genes that are arranged, so that the infectivity also changes. The process of changing the nucleotide bases in each isolate to produce different amino acids is a natural adaptation of the virus to the environment in Indonesia [8]; [9]; [12]; [13]; 16].

The results of the analysis continued with the reconstruction of phylogenetic trees to determine the kinship of Indonesian isolates with isolates from other countries. Phylogenetic analysis generally classifies ORSV isolates based on their geographical area. [16] have previously reported that ORSV isolates isolated from Phalaenopsis amabilis from Bogor, Magelang, and Bali had close kinship with isolates from Germany, China, Taiwan, Brazil, and America. These countries also reported [6] had close relations with ORSV isolates from Indonesia other than Thailand, India, South Korea, Japan, and Singapore.

Information about orchid diseases caused by ORSV in Indonesia is still very little. Several molecular detection and ORSV research studies conducted in Indonesia include [4] detecting and identifying viruses that attack orchids in Indonesia with sampling locations in 12 orchid nurseries in East Jakarta, Bogor, Sukabumi, Yogyakarta, Ujung Pandang, and Bali. Furthermore, the detection and characterization of ORSV was carried out on various types of orchid cultivation with capture locations on Mount Sindur, West Java, Bogor, Magelang, Bogor, Bandung, Magelang, Surabaya, and Malang. In addition, [12]; [16] also carried out molecular detection and characterization of ORSV on several Phalaenopsis from natural orchids and cultured orchids with sampling locations in Java and Bali. 


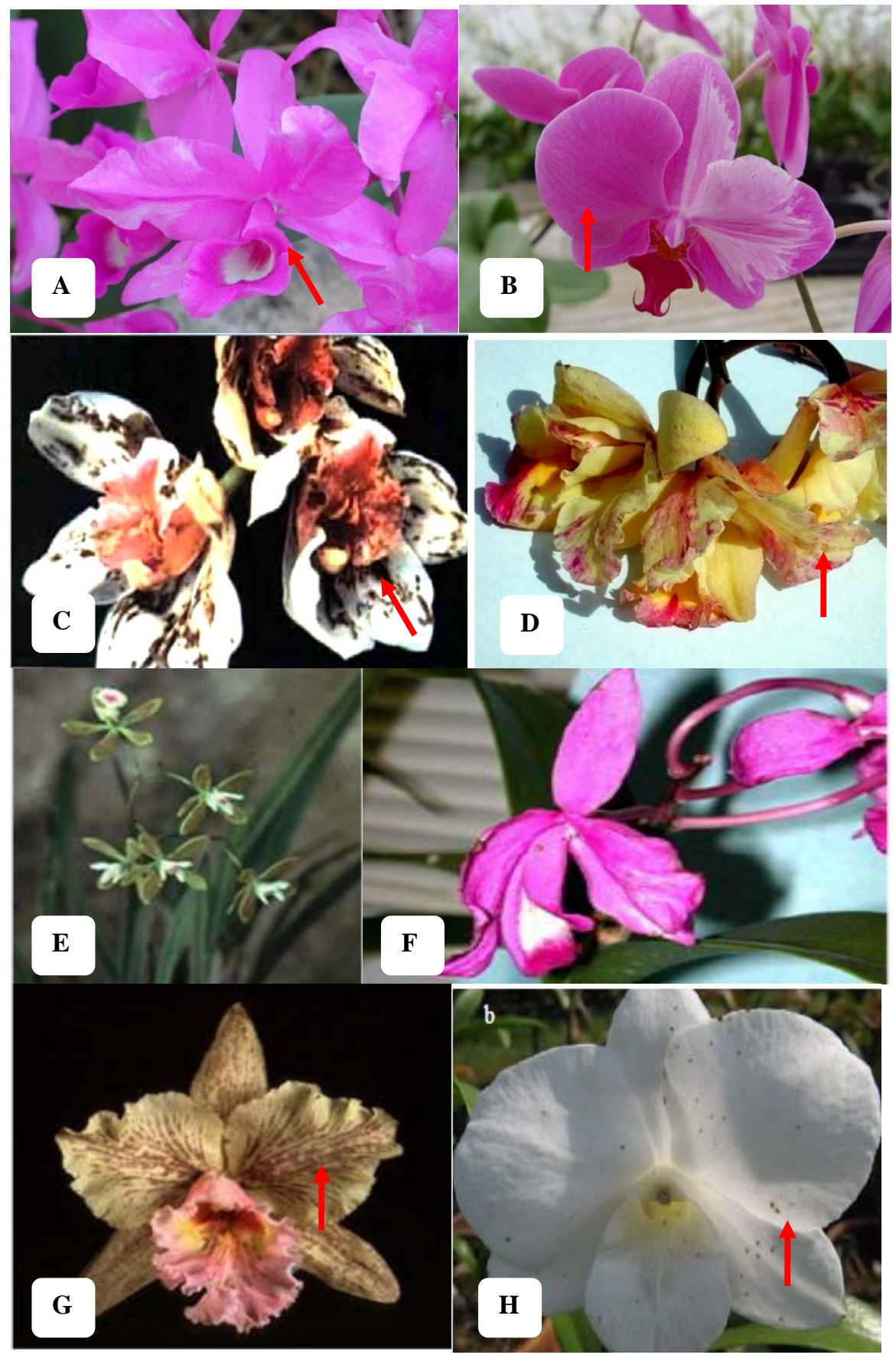

Fig. 3: Symptoms of ORSV infection in orchids. Color breaking on: (A). Phalaenopsis, (B). Cattleya. Sepal and petal pigment abnormalities in: (C). Cymbidium, (D). Cattleya. Malformations and flower shape distortion in: (E). Encyclia, (F). Cattleya sp., And Necrotic at: (G). Cattleya, (H). Dendrobium. (Arrow: symptoms of infection) [6]; [18]

\section{Efforts to Control Virus Infection}

Some of the successful efforts to control viral infections in orchids have been carried out on a laboratory scale. Treatment of $150 \mathrm{~g} / \mathrm{l}$ neem leaf extract applied before mechanical inoculation ORSV showed better results for disease prevention and control. Such treatment can inhibit infection by $37.5 \%$ [8].

[8] reported that ribavirin antivirals can be used to eliminate viruses in Dendrobium orchids at a minimum concentration of $30 \mathrm{ppm}$, the use of antiviral compounds is very important in the effort to culture tissue of virus-free orchid plants. Besides antiviral ribavirin salicylic acid can also be used. Then [8] was reported that the application of Bactocyne bactericidal-fungicide (trademark) is proven to be able to control viral infections and mixed infections of viruses, bacteria and fungi.

Biological disease control is reportedly possible by induction of endophytic mycorrhiza-induced resistance [7]; [11]; [15] and plant vaccine. In the realm of computer science can be done using applications based on artificial intelligence Nextren, and Fuzzy Tsukamoto, Build and Fix, and Black Box methods based on Android. 


\section{Conclusion}

Disease identification techniques as the initial stage of disease control include variations in infection symptoms, host range testing, testing of viral titers, observation of particle morphology, genome detection, and analysis of DNA and amino acid sequences. Efforts to control disease can be done through preventive and eradicative actions chemically, biologically, and based on artificial intelligence.

\section{References}

[1] Akin HM (2006), "Virologi Tumbuhan”, Kanisius, Yogyakarta, pp. 188

[2] Corbett KN (1967), Some distinguish characteristhic of the orchid strain of Tobacco Mosaic Virus, The Handbook on Orchid Pest and Disease, American Orchid Soc., vol. 4, pp. 62-100.

[3] Hull H (2002), Matthews Plant Virology. 4th Eds. San Diego, Academic Press.

[4] Inouye N \& Gara IW (1996), Detection and identificationof virus of orchid in Indonesia, Bull. Res. Inst., Bioresour., Okayama Univ., vol. 4, pp: 109-118.

[5] Kumalawati AD, Abdullah S, Daryono BS, \& Mahfut (2011), Study on genetic diversity and conservation of orchids in Wonosadi forest, Gunung Kidul based on molecular analysis. Proceeding International Conference on Biological Science. Yogyakarta, Indonesia. pp. 54.

[6] Lakani I, Suastika G, Mattjik N, \& Damayanti TA (2010), Identification and Molecular Characterization of Odontoglosum ringspot virus (ORSV) from Bogor, Indonesia. Hayati Journal of Biosciences, vol. 17, no. 2, pp. 101-104.

[7] Mahfut (2020a), Effectiveness Test of Orchid Mycorrhizal Isolate (Ceratorhiza and Trichoderma) Indonesia and Its Role as a Biofertilizer: Critical Overview, Current Research Trends in Biological Science Vol. 1. Book Publisher International, India \& United Kingdom, pp. 139-145.

[8] Mahfut (2020b), Indonesia Darurat Konservasi: Sudah Amankah Kebun Raya Kita?, Prosiding Seminar Nasional Biodiversitas Indonesia, Jurusan Biologi, Fakultas Sains dan Teknologi, UIN Alauddin Makassar, pp. 1-6.

[9] Mahfut \& Daryono BS (2014), Deteksi Odontoglossum ringspot virus (ORSV) Terhadap Anggrek Alam di Hutan Wonosadi, Gunung Kidul, Biogenesis, vol. 2, no. 2, pp. 101-108.

[10] Mahfut, Daryono BS, Indrianto A, \& Somowiyarjo S (2019a), Plant-Virus Interaction on Orchids Infected Odontoglossum ringspot virus (ORSV) in Bogor Botanical Garden, Indonesia, The 1st International Conference on Science and Technology (ICoST), Makassar, Indonesia.

[11] Mahfut, Daryono BS, Indrianto A, \& Somowiyarjo S (2019b), Effectiveness Test of Orchid Mycorrhizal Isolate (Ceratorhiza and Trichoderma) Indonesia and Its Role as a Biofertilizer, Annual Research \& Review in Biology, vol. 33(4), pp. 1-7.

[12] Mahfut, Daryono BS, Joko T, \& Somowiyarjo S (2016a), Survei Odontoglossum ringspot virus (ORSV) yang Menginfeksi Anggrek Alam Tropis di Indonesia, Jurnal Perlindungan Tanaman Indonesia, vol. 20, no. 1, pp. 1-6.

[13] Mahfut, Daryono BS, \& Somowiyarjo S (2017a), Deteksi Odontoglossum ringspot virus (ORSV) yang Menginfeksi Anggrek Asli Koleksi Kebun Raya di Indonesia, Jurnal Fitopatologi Indonesia, vol. 13, no. 1, pp. 1-8.

[14] Mahfut, Daryono, BS \& Somowiyarjo S (2017b), Identifikasi Molekuler DNA Kloroplas Pada Anggrek Terinfeksi Odontoglossum ringspot virus (ORSV) di Magelang, Jawa Tengah Prosiding Seminar Nasional Pengendalian Penyakit Pada Tanaman Pertanian Ramah Lingkungan II Perhimpunan Fitopatologi Indonesia Komisariat Daerah Yogyakarta, Solo, dan Semarang, Yogyakarta, Indonesia, pp. 354-360.

[15] Mahfut, Indrianto A, Somowiyarjo S, \& Daryono, BS (2020), Molecular phylogeny of orchids mycorrhiza isolated from native tropical orchids in Indonesia. Malaysian Journal of Microbiology, vol. 16(1) 2020, pp. 68-72.

[16] Mahfut, Joko T, and Daryono BS (2016b), Molecular Characterization Molecular of Odontoglossum ringspot virus (ORSV) in Jawa and Bali, Indonesia, Asian Journal of Plant Pathology, vol. 10, no. 1-2, pp. 9-14.

[17] Matthews REF (1992), Plant Fundamental of Plant Virology, California, Academic Press Inc.

[18] Robert TM \& Vendrame WA (2005), Color Break in Orchid Flowers, Proc. Fla. State and Hort. Soc., vol 118, pp. 287-288. 